\title{
The New Caledonia mantle section: tracking source depletion and contamination processes in a supra- subduction setting
}

A. MONTANINI ${ }^{1}$, A. SECCHIARI ${ }^{1}$, D. BOSCH ${ }^{2}$, D. CLUZEL ${ }^{3}$, P. MACERA ${ }^{4}$

${ }^{1}$ University of Parma, Italy; alessandra.montanini@unipr.it,

${ }^{2}$ University of Montpellier, France;

delphine.bosch@umontpellier.fr

${ }^{3}$ Université de la Nouvelle-Calédonie, New Caledonia;

Dominique.cluzel@unc.nc

${ }^{4}$ University of Pisa, Italy; patrizia.macera@unipi.it

The New Caledonia Ophiolite (NCO) hosts one of the largest obducted mantle sections worldwide, offering a unique opportunity to investigate key mantle processes. The ophiolite includes refractory harzburgites, locally overlain by mafic-ultramafic cumulates, and minor lherzolites. Here we present the results of our recent geochemical and $\mathrm{Sr}-\mathrm{Nd}-\mathrm{Pb}$ isotopic studies on fresh or slightly serpentinized peridotites. The lherzolites display a moderately depleted, abyssal-type signature which may be reproduced by small amounts of fractional melting of a garnet lherzolite precursor $(\sim 4 \%)$, followed by $4 \%-5 \%$ melting in the spinel peridotite field. $\mathrm{Nd}$ isotope compositions are consistent with derivation from an asthenospheric mantle source that experienced a recent MORB-producing depletion event. The harzburgites are Cpxfree highly refractory rocks characterised by remarkably low REE concentrations $(<0.1 \mathrm{xCh})$ and "U-shaped" REE profiles. HREE composition can be reproduced by a first phase of melt depletion in dry conditions ( $15 \%$ fractional melting), followed by hydrous melting in a subduction zone setting (up to $15 \%-18 \%$ ). $\mathrm{Nd}$ isotopic ratios range from unradiogenic to radiogenic and negatively correlate with $\mathrm{Sr}$ isotopes. $\mathrm{Pb}$ isotopes cover a wide range, trending from DMM toward enriched, sediment-like, compositions. Enrichment in FME, LREE-MREE and $\mathrm{Nb}, \mathrm{Zr}$, Hf, coupled with the presence of secondary interstitial phases, may be explained by syn- and post-melting interactions with different subduction-related components. Contamination may have occurred both as result of fluid influx from the subducted slab and through subsequent interaction with subduction-related melts carrying a component of sedimentary origin. A recent HSE and Os isotope study [1] provides additional insights on the evolution of the NCO mantle section. (Presentation sponsored by PRIN2017 Programme, Project 2017KY5ZX8)

[1] Secchiari et al. (2020) Lithos 354-355 